\title{
Özel Yetenekli Öğrencilerin Sosyal Becerilerinin Gelişiminde Müzik Eğitiminin Etkisi*
}

The Effect of Music Education in the Improvement of Gifted and Talented Students' Social Skills

\author{
Melike Bolat** - Tülün Malkoç***
}

\begin{abstract}
In this study, it was carried out to enable gifted and talented children to discover, recognize and develop their social skills through musical education. In this research using experimental method; It has been investigated how effective the social skills levels of gifted and talented children and music education can be. The study group of the research consisted of students studying in the Gifted and Talented Education Program (ÜYEP) in a private educational institution in Istanbul. The Social Skills Evaluation Scale (7-12 years old) developed by Gönül Akçamete and Hasan Avcioğlu was applied to the experiment $(n=9)$ and control $(n=9)$ groups, which were randomly selected among 18 students. Experimental group; one hour per week an enriched to improve social skills developed by researcher with researcher music while working training program, and also one hour per week at the Ministry of Education with the school's music teacher, music lessons and continued their musical education through the program. The control group continued their music education with the music teacher of the school for two hours a week with the Ministry of National Education Music lesson program. At the end of 12 weeks, a post-test was applied to the experimental and control groups and the data were analyzed statistically. In the results obtained by analyzing the data; at the end of the application process, a positive development was observed in the experimental group's basic social skills, basic speaking skills, initiation skills, group business skills, emotional skills, self-control skills and cognitive skills. In the control group; basic conversational skills, relationship skills to initiate, maintain relations skills, the ability to welcome the results were seen in a positive direction in the development of guidelines making skills and cognitive skills. It was confirmed that music education improves the social skills of the students in both the experimental and control groups.
\end{abstract}

Structured Abstract: This study aims to adress not only discover musically-talented students, but also create a positive difference in their social attitudes. Through the music education in this study, the gifted and talented students are given a chance to realize their self emotional awarenes. In this light, the focal point of this research is to find out what is the music education in the improvement of gifted and talented students' social skills. Further, this research covers the concepts of gifted- talented and social skills. The study also emphasizes the importance of the students' academic and individual capacity as well as their social skills for the adaptation of their social environment. In addition, some various education approaches for gifted and

\footnotetext{
*Bu çalışma, Doç. Dr. Tülün MALKOÇ danışmanlığında, Melike BOLAT tarafından hazırlanan ve 2015 yılında kaul edilen "Müzik Eğitiminin Üstün Zekâlı Ve Yetenekli Öğrencilerin Sosyal Becerilerinin Gelişimine Etkisi” adlı doktora tezinden güncellenerek üretilmiştir.

** Dr. Öğr. Üyesi, Zonguldak Bülent Ecevit Üniversitesi, Devlet Konservatuvarı, Sahne Sanatları Bölümü, Assist. Prof., Zonguldak Bulent Ecevit University, State Conservatory, Performing Arts Department. ORCID:0000-0003-3215-9975, bolatmelike@ gmail.com **** Doç.Dr., Marmara Üniversitesi, Atatürk Eğitim Fakültesi, Müzik Anabilim Dalı, Assoc. Prof., Marmara University, Atatürk Faculty of Education, Music Teacher Education, Department. ORCID:0000-0002-4276-8574, tmalkoc@marmara.edu.tr
}

Cite as/ Atıf: Bolat, M. \& Malkoç, T. (2021). Özel yetenekli öğrencilerin sosyal becerilerinin gelişiminde müzik eğitiminin etkisi. Turkish Studies, 16(5), 1463-1481. https://dx.doi.org/10.7827/TurkishStudies.49974

Received/Geliş: 16 March/Mart 2021

Accepted/Kabul: 25 October/Ekim 2021

Published/Yayın: 30 October/Ekim 2021
Checked by plagiarism software

CC BY-NC 4.0 
talented students are given. The vital point of the research is to be a source for the teachers of Music and for the researches in the future. The implemented methods of the researches are the randomized protest-posttest control group design. The students whose IQs are between 130-160 points are trained one hour a week both in the enriching musical programme and MEB (Ministry of Education) music teaching program for 12 weeks. The experimental group is observed during 12 weeks and the findings are evaulated. In the control group, only MEB music teaching program has been implemented. In both groups, the evaluations are done before and after the experiement. As the study group of the research $(\mathrm{N}=18)$ has been constituted of the second grade primary school students in the Gifted Education Programme, The quasi-experimental design is implemented. The study group has been formed with experimental $(n=9)$ and control $(n=9)$ group by using random method, and the avarage age of both group is 94 months.(7 years and 10 months). In the research, the Social Skills Evaluation Scale (7-12 years old) (SDBÖ) is implemented by Akçamete and Avc1oğlu (2005) has been used. SBDÖ is a Likert-typed scale.

Finding I: The first finding of the study is to find out that there is no difference in social skills between the experimental and control groups. According to the results of the analyzes regarding the first finding of the research, there is no difference between the social skills levels between the experimental and control groups.

Finding II: The second finding of the study is to investigate that there is a difference between the experimental group's pretest and posttest scores in favor of the posttest. According to the second finding of the study, there is a difference between the pretest and posttest scores of the experimental group in favor of the posttest. When the pre-test and post-test scores of the experiment were compared, SDBÖ sub-dimensions post-test results were higher than the pretest results. Basic Social Skills (TSB), Basic Speaking Skills (TKB), Relationship Initiation Skills (IBB), Group Business Skills (IOP), Emotional Skills (DB), Self-Controlling Skills (KKEB) and Cognitive Skills (BB) posttest score higher than the pretest score.

Finding III: The third finding of the study is to investigate that there is no difference between the pre-test and post-test scores of the control group in favor of the post-test. According to the third finding of the study, the posttest scores of the control group on Basic Social Skills (TSB), Relationship Initiation Skills (IBB), Relationship Sustainability Skills (PSD), Adoption Skills (SKEB), Instructional Skills (YVB) and Cognitive Skills (BB) pre-test higher than the score.

Finding IV: The fourth finding of the study is aimed at investigating that there is a difference in favor of the experimental group between the posttest scores of the experimental group and the control group. According to the fourth finding of the study, there is no significant difference between the sub-dimensions of SDBÖ, which are Basic Social Skills (TSB), Basic Speaking Skills (TKB), Advanced Speaking Skills (IKB), Relationship Maintenance Skills (ISB), Group Business Skills (GIYYB), Emotional Skills (DB), Self-Control Skills (KKEB), Skills for Coping with Aggressive Behaviors (SDBÇB) Accepting Results Skills (SKEB), Instructional Skills (YVB), Cognitive Skills (BB) levels.

Table 1: The Comparison of Improving Social Skills in Experimental and Control Groups

\begin{tabular}{ll}
\multicolumn{1}{c}{ Experimental group } & \multicolumn{1}{c}{ Control Group } \\
\hline Basic Social Skills (TSB) & Basic Social Skills (TSB) \\
Basic Speaking Skills (TKB) & Relationship Initiation Skills (IBB) \\
Relationship Initiation Skills (IBB) & Relationship Maintenance Skills (PSD) \\
Group Business Skills (GIYY) & Accepting Results Skills (SKEB) \\
Emotional Skills (DB) & Instructional Verne Skills (YVB) \\
Self-Control Skills (KKEB) & Cognitive Skills (BB) \\
Cognitive Skills (BB) & \\
\hline
\end{tabular}

Table 1 shows the music education program applied to the control group does not make a difference on social skills sub-dimensions; Basic Speaking Skills (TKB), Group Business Skills (GİYB), Emotional Skills (DB) and Self-Control Skills (ht ).

The common findings of the two application methods are the development of Basic Social Skills (TSB), Relationship Initiation Skills (IA) and Cognitive Skills. Apart from these social skills, social skills in different areas were developed in the experimental and control groups. It is seen that the musical education applied to the experimental group did not make a difference on the Relationship Maintenance Skills (PSD) 
and the Acceptance of Results (SKEB). It has been appeared that the programme applied to experimental group has deficiencies and it needs to be developed.

In the study, it was seen that the application made in the experimental group was effective. It is thought that the music education program, which consists of games and group work, is effective and useful in the development of social skills. However, it could not develop all of the social skills. It is recommended to improve the music education program applied to the experimental group and to complete the deficiencies. At the same time, the difference in favor of the posttest scores in the control group shows that the music education program conducted with the control group is also effective. It is clearly seen in the research results that the methodological differences of both the program enriched by the researcher and the program carried out in accordance with the curriculum improve different areas of social skills. Based on the findings and results; according to the indication that music education improves social skills in different sub-dimensions in the experimental and control groups. It is recommended to give importance to the music education provided in the education system.

It is suggested that the music education program be renewed for the development of social skills, not in order to discover the talent of children who are defined as gifted and talented, but to enrich the music education programs based on the need for music education.

Keywords: Music education, social skills, special education, gifted, talented

Öz: Bu çalışma, özel yetenekli çocukların sosyal becerilerini müzik eğitimi yoluyla keşfetmelerini, tanımalarını, geliştirmelerini sağlamak amacıyla yapılmıştır. Deneysel metod kullanılan bu araştırmada; özel yetenekli çocukların sosyal beceri düzeyleri üzerine müzik eğitiminin etkisinin ne derece etkili olabileceği araştırılmıştır. Araştırmanın çalışma grubunu İstanbul ilinde özel bir eğitim kurumunda Üstün Yetenekliler Eğitim Programı'nda (ÜYEP) öğrenim gören öğrenciler oluşturmuştur. 18 öğrenci arasında rastgele seçilerek oluşturulan deney $(n=9)$ ve kontrol $(n=9)$ grubuna, Akçamete ve Avcıoğlu'nun (2005) geliştirdiği Sosyal Becerileri Değerlendirme Ölçeği (7-12 Yaş) uygulanmıştır. Deney grubu; haftada 1 saat araştırmacı ile araştırmacı tarafından geliştirilen sosyal becerileri arttırmaya yönelik zenginleştirilmiş bir müzik öğretim programı çalışırken, haftada 1 saat de okulun müzik öğretmeni ile Milli Eğitim Bakanlığı Müzik dersi öğretim programı ile müzik eğitimine devam etmiştir. Kontrol grubu ise haftada iki saat okulun müzik öğretmeni ile Milli Eğitim Bakanlığı Müzik dersi programıyla müzik eğitimine devam etmiştir. 12 hafta sonunda deney ve kontrol grubuna son test uygulanarak Sosyal beceri düzeyleri ile ilgili veriler istatistiksel olarak analiz edilmiştir. Verilerin analiz edilmesiyle elde edilen sonuçlarda; uygulama süreci sonunda deney grubunun, temel sosyal becerileri, temel konuşma becerileri, ilişkiyi başlatma becerileri, grupla iş yapma becerileri, duygusal becerileri, kendini kontrol etme becerileri ve bilişsel becerilerinde pozitif yönde gelişim görülmüş̧ür. Kontrol grubunda ise; temel konuşma becerileri, ilişkiyi başlatma becerileri, ilişkiyi sürdürme becerileri, sonuçları kabul etme becerileri, yönerge verme becerileri ve bilişsel becerilerinde pozitif yönde gelişim görülmüştür. Deney ve Kontrol gruplarının her ikisi için de müzik eğitiminin öğrencilerin sosyal becerilerini geliştirdiği sonucu doğrulanmıştır.

Anahtar Kelimeler: Müzik eğitimi, sosyal beceri, özel eğitim, üstün zekâ, üstün yetenek, özel yetenek

\section{Giriş}

Akademik olarak üstün zekâlı ve yetenekli öğrencilerin eğitimi özel bir ihtiyaç grubu içerisinde yer almaya devam etmektedir. Üstün zekâ ve üstün yetenek kavramlarına göz attığımızda; İskoçya'da "able" yetenekli; Galler'de "more able" ve "talented" çok yetenekli; İngiltere'de ise "gifted- talented" üstün zekâlı ve yetenekli tanımlamaları dikkat çekmektedir. "Gifted" olarak adlandırılan çocuklar insani yetenekleri, "talented" olarak adlandırılanlar insani başarıları ile birbirinden farklılık gösterirler (Akt.Sternberg, 2004). "Genius", ise alış1lmadık derecedeki zekâ, kabiliyet veya artistik yeteneği ya da özel yetenek veya kabiliyeti ve bir alanda çok zeki ve yetenekli kişiyi tanımlamak için kullanılmaktadır (Hornby, 2000:494). 
Literatürde kullanılmakta olan "üstün” kelimesini içeren tanımlamaların aynı anlama gelmek üzere daha az kategorize edici olması amaçlanarak "özel yetenek" kavramının kullanılması tercih edilmeye başlanmıştır. Özel yetenek kavramı, genel zihinsel yetenek, özel akademik yetenek dil, matematik, fen bilimleri sosyal bilimler, liderlik, yaratıcilık, görsel ve işitsel sanatlar, psikomotor becerileri kapsamaktadır. Özel yetenekli birey ile, zeka, yaratıcılık, sanat, liderlik kapasitesi, motivasyon veya özel akademik alanlarda yaşıtlarına göre yüksek düzeyde performans gösteren birey ifade edilmektedir (Bilgiç vd., 2013:7).

Özel yeteneklilerin eğitimi ile ilgili yapılan bir kongre raporunda özel yetenekliler; genel zihinsel kapasite, özel akademik yetenek, yaratıcı ve üretken düşünce, liderlik yeteneği, görsel ve performans sanatlarında yetenek, psikomotor yetenek alanlarının birinde veya birkaçının birleşiminde ortaya çıkan ya da potansiyeli olan bireyler olarak tanımlanmışlardır (U.S. Commissioner of Education, 1972).

Özel yetenekli öğrencilerin genel ihtiyaçlarının başında tanılama ihtiyacı gelir. Aile, öğretmen ve arkadaşlarından oluşan çevresel ihtiyaçlar, sosyal, kültürel ve etnik ihtiyaçlar, bilişsel ihtiyaçlar (uygulanacak uygun müfredatın geliştirilmesi vb.), kişiler arası ilişkileri geliştirmeleri, akran etkileşimi, kariyer rehberliği ihtiyacı sırayı alır. Diğer ihtiyaç ise başarısızlığa karşı alınacak önlemlerdir. Çünkü sosyal uyum eksikliği, kendinin ve yeteneklerinin inkârı, ortalama yetenek algısı, verilen görevi tamamlayamama, başkalarının kusurlarıyla ilgili sabırsızlık, paylaşma direnci, destek ve yardımı reddetme, üretme ve girişim eksikliği başarısızlığın altında yatan sebepler olabilir (Öznacar \& Bildiren, 2013:11-12).

Ortalamanın üstünde IQ puanı almış olan özel yetenekli öğrencilerin, okuldaki akademik başarısızlığının nedeni zekâlarındaki eksiklik değil, duygusal yaşamlarını kontrol etme yeteneklerinin bozulması olarak açıklanabilmektedir. (Goleman, 1998:44 ). Zihinsel olarak özel yetenekli çocukların (IQ $\geq 130$ ) sosyo-duygusal sorunlar ve / veya okul başarısızlığı veya uyumsuzluk nedeniyle pediatri veya çocuk nöropsikiyatri kliniklerine sevk edilmesi yaygındır. Wechsler'in zekâ profilinde önemli bir bölüm olan sözel performans farkl1lığına (SVPD) yansıyan ve heterojen bir gelişimsel sergileyen özel yeteneklilerin, duygusal ve davranışsal olarak daha zayıf olduğu ve bu durumun psikopatoloji için bir risk göstergesi olabileceğini düşündürmektedir (Guenole vd., 2015).

Özel yetenekli öğrencilerin, bir veya birkaç alanda çok üst düzey yeteneklere sahip olsa da; diğer bazı alanlarda örneğin; sosyal ilişkiler, sanat veya motor beceriler konusunda yaşıtları hatta bazen yaşıtlarının bile gerisinde gelişim gösterebilmektedirler. Bu noktada üstün yetenekli çocukların sadece başarılı oldukları alanları değil, diğer zayıf oldukları alanları da fark ederek; bu alan/alanlardaki becerilerinin de geliştirmesini sağlayacak eğitimsel önlemlerin alınması gerekmektedir (Sisk, 1987, Akt. Dağlığlu, 2010:76).

Bilim ve Sanat Merkezinde (BİLSEM) bulunan özel yetenekli bireylerde gözlemlenen davranış problemleri ve öğretmenlerin bu davranış problemleriyle başa çıkmada kullandıkları yöntemler konusunda yapılan araştırmada; öğretmenler sınıf ortamında en yaygın olarak gördükleri davranış problemlerinin dinlememe-başkalarının sözünü kesme, çok soru sorma, ders dışı etkinliklerle ilgilenme ve çok hareketli olma, sınıfta gürültü yapma ve sınıfta izinsiz hareket etme, iletişim kurmama, sosyal beceri eksikliği, ekip çalışmasından kaçınma, sözel şiddet, öfke kontrolünde güçlük ve ağlama gibi davranışlar olduğunu belirtmişlerdir (Keleş, 2020).

Eğitimin amacı, öğrencilerin akademik becerilerinin gelişmesine yardımcı olmak kadar kişisel ve sosyal çevreye uyumları için gerekli becerileri geliştirmektir. Sınıf ve okul ortamları öğrencilerin her yönüyle gelişimi için uygun firsatları hazırlayan ortamlardır (Akkök, 1996:1).

Eğitsel planlamaların içerisinde sosyal beceri gelişimine yer verilmesi önem taşımaktadır. Sosyal beceri, sosyal etkileşim sağlamaya uygun düsen davranışların toplamı olarak tanımlanmıştır (Erwin, 2000). Yüksel'in (1997) çalışması incelendiğinde; sosyal beceri eğitiminin, sosyal 
becerilerin kazandırılmasına yönelik çoğunlukla davranışçı yöntemleri benimseyen, performansa dayalı, aktif bireysel ya da grup olarak uygulanan bir eğitim ve tedavi yöntemi olduğu anlaşılmaktadır (Yüksel, 1997:4-48). Karakter Gelişimi ve Sosyal Beceriler eğitimi, insan yaşamını anlamlı ve üretken hale getirebilmek, bireylerin yaşama dair amaç edinmelerini sağlamak, bununla birlikte sağlıklı gelişen bir toplum ortaya çıkarabilmek için, toplum içerisinde bir takım erdemler geliştirme çabasıdır. Bu eğitim, evrensel ve toplumsal bir takım değerlerin okul yaşamına sistemli olarak yerleştirilmesi sürecidir (Akgünlü vd., 2005). Sosyal beceriler, bir çocuğun diğer çocuklara yönelik davranışlarını da kapsadığı gibi; iyi ilişkiler kurabilme, başkalarının haklarına, duygularına saygı duyma, grup normlarını dikkate alma gibi davranışlarla çocuğun isteklerini elde etmesini de sağlamaktadır (Çetin vd., 2001:28- 29). Sosyal beceriler; bireyin akranlarıla ilişkili becerilerini, akademik becerilerini, kendini kontrol etme becerilerini, uyum becerilerini ve atılganlık becerilerini içermektedir. Sosyal becerilerle ilgili en önemli beceri grubunun, çocukların kişiler arası ilişkilerini destekleyen beceriler olduğu söylenebilir. Çocuğun dil, gülümseme, göz kontağı kurma, dinleme gibi basit iletişim becerilerine ve grupla çalışma imkânı için gruba girme, işbirliği ve yardımlaşma gibi giriş ve işbirliği davranışlarına sahip olması gerekmektedir (Ogelman vd., 2012).

Sosyal beceriler ile sosyal yeterlik arasında (sosyal etkileşim, sosyal ilişkiler vb) ortak noktalar olmakla beraber, sosyal yeterliğe sahip bireylerin birçok sosyal beceriyi rahatlıkla uygulayabildiği, sosyal yetersizliklerin sosyal beceri yetersizliği olarak da ifade edildiği görülmektedir. Sosyal yeterlik ve olgunluk çocuktaki kapasiteyi, sosyal beceri ise davranış kalıplarını ifade etmektedir sosyal yeterlik, çocukları akran şiddeti ve dışlanmaya karşı korumaktadır. Sosyal yeterliği düşük düzeyde olan çocukların akranları tarafından kabul edilmemesi, akademik başarılarının düşük olması, sosyal uyumsuzluk yaşamaları, okulu bırakmaları, ileriki yıllarda akıl sağlığı problemleri ile karşılaşmaları yüksek olasılıklar arasındadır (Gülay \& Akman, 2009: 21, 25).

Malezya'daki özel yetenekli öğrenciler arasındaki sosyal becerilerin boyutları ile empati ilişkileri incelendiğinde; sosyal becerilerin boyutlarının tamamı ile empati arasında pozitif ilişki olduğu; empati ile liderlik becerisi, empati ile başkalarını etkileme yeteneği ve empati ile iletişim arasında güçlü ilişkiler olduğu sonucuna varılmıştır. Empati kurma ile takım yetenekleri arasındaki ilişkinin zayıf bulunan beceriler arasında olması ve öğrencilerin başkalarıyla bağ kurmakta güçlük çekmeleri konusunda eğitim sağlamaya odaklanılması gerektiği belirtilmiştir (Ishak vd., 2014).

Sosyal duygusal beceriler ve akran ilişkileri karşılıklı etkileşim içerisinde olduğu, sosyal duygusal becerilerin geliştikçe akran ilişkilerinin de geliştiği; akran ilişkileri geliştikçe sosyal duygusal beceriler ve sosyal uyumun arttığı görülmektedir. Özel yetenekli öğrencilerin akranlarıyla olan ilişkilerini artırmak için sosyal duygusal becerilerinin desteklenmesi gerekmektedir (Yıldırım, 2020: 87).

Üstün zekalılık etiketi, özel yetenekli bireyleri bilişsel, duygusal, sosyal ve fiziksel nitelikler açısından kendileri gibi olmayan akranlarından ayırmaya yarar. Fakat özel sınıflardaki özel yetenekli çocuklar, sosyal çevrelerinden dışlandıklarını ve üstün zekalılıklarından dolayı sosyal sorunlarla karşılaştıklarını daha sık bildirmektedirler. Özel yetenekliler için oluşturulan homojen bir sınıf, ait olma duygusunu destekleyerek koruyucu bir ortam sağlayabilir. Ayrıca, kaynaştırmalı sınıf ortamında olumsuz etiketlemenin etkilerini kısmen dengeleyebilecek uygun bir sosyal çerçeve içerisinde olabilirler. Bu durum, akademik başarı söz konusu olduğunda öğrencilere fayda sağlıyor olmasının bedeli bir dizi kişisel-sosyal uyumları üzerindeki olumsuz etkidir. Bir yandan da kaynaştırmalı sınıflardaki özel yetenekli öğrenciler, normal öğrenciler için akademik benlik kavramlarında azalmaya yol açabilir, değerlendirilme kaygısını artırabilir ve refahlarını olumsuz yönde etkileyebilir. $\mathrm{Bu}$ sebeple program planlayıcılarının, özel yetenekliler için uygulanacak eğitim süreçlerini dikkatlice düşünmeleri gerekmektedir (Zeidner, Schleyer, 1999). 
Bilim ve Sanat Merkezlerinde (BİLSEM) yapılan başka bir araştırmada uygulanan (ÖYKIDEP- Özel Yetenekli Öğrencilere Yönelik Kişiler Arası İletişim Becerilerini Destekleyici Program); etkin dinleme, açık iletişim, beden dili, empati, etik iletişim, ortak iletişim ve sanal iletişim alanlarında sorun yaşayan özel yetenekli öğrencilerin iletişim beceri düzeylerini arttırma yönünde olumlu etki ettiği görülmüștür. Bu sebeple de BİLSEM'lerde iletişim eksenli yürütülecek çalışmalara ihtiyaç duyulmakta olduğu belirtilmiştir (Kara, 2020).

Her öğrencinin öğrenme stillerinin farklılık gösterdiği göz önüne alındığında özel yetenekli öğrencilerin görsel ve kinestetik öğrenme stillerini kullanmayı tercih ettiği görülmektedir. Türkiye'deki eğitim uygulamaları; kalabalık sınıflar ve ağırlıklı olarak işitsel öğrenme stiline sahip eğitim süreçleri, özel yeteneklilerin ağırlıklı olarak kinestetik öğrenme stilini kullandıkları düşünüldüğünde, normal kaynaşmalı sınıflar dezavantajlar oluşturabilmektedir (Altun ve Yazıcı, 2010; 201). Türkiye'de yedi bölgede hizmet veren ilkokul ve ortaokul öğretmenleri zihinsel özel yetenekliler ile diğer öğrencilerin aynı sınıflarda olmamaları gerektiğini; özel yeteneklilerin normal eğitim gördükleri sınıflarda sıkılabileceklerini ve yeteneklerini etkin bir şekilde kullanamadıklarını belirmişlerdir (Altıntaş \& Özdemir, 2012).

Özel yetenekli öğrencilerin eğitimi ile ilgilenen bilim çevrelerinin ana meselesi, özel yetenekli öğrencilerin en başarısız ve öğrenme güçlügü̈ taşıyan öğrenciler kadar özel eğitime ihtiyaç duydukları yönündedir (Ercan, 2004).

Özel yeteneklilerin eğitiminde yapılan uygulamalarda; farklılaştırılmış, bireyselleştirilmiş, zenginleştirilmiş, hızlandırılmış çoklu modellere yer verildiği görülmektedir.

Yüksek zihinsel zekânın her zaman iyi öğrenme ile ilişkili olmadığı fikri ile beraber didaktik uygulamalarda özel yeteneklilerin kitlesel okul faaliyetlerinde zorluklarla karşılaştığı gözleminden yola çıkılan başka bir model Üstün Yetenekli Çocuklar İçin Kişiselleştirilmiş Eğitim Modelidir (Personalized Model of Education for Gifted Children). 1-müfredatın zenginleştirilmesi, 2-öğretimin farklılaştırılması ve 3-üstün yetenekli çocuklar için mentorluk'u (danışmanlığı) kapsayan üç bileşenden oluşan eğitim modelinde etkinlikler sınıf içi ve sınıftan ayrı olarak uygulanmaktadır. Tüm müfredat üniteleri, özel yetenekli çocukların ilgi alanlarından (müzik, sanat, matematik, dil, kimya, fizik ve diğerleri) yapılan seçimlere dayanmaktadır (Kelemen, 2010).

Bilim-teknoloji-fen-mühendislik ve matematik (STEM; Sciences-Technology-EngineeringMathematics) alanlarında eğitim gören özel yetenekli öğrencilerde yaratıcılığ yeteneklerini, eğitim aldığ 1 alana entegre edeceği bağlantı ağlarını inşa etme ihtiyacını hesaba katarak tasarlanan herhangi bir eğitim sisteminde sanat ve zanaatın katılması bütünleştirici yaklaşımda önemlidir. Bu tür programlardan üç şey istenmelidir: Birincisi, bireysel tercihlerin keşfedilebilmesi için öğrencileri mümkün olan en geniş sanat ve zanaat yelpazesiyle tanıştıracak kadar çeşitli olmaları. İkinci olarak, müfredatın öğrencilerin ilgi alanlarını derin ve kişisel olarak anlamlı bir düzeyde keşfetmelerine ve geliştirmelerine yeterli zamanı ayırmalarını sağlayacak kadar esnekliğe sahip olması. Üçüncüsü, sanat ve zanaat bilgi ve becerilerinin nasıl kullanılacakları bağlamında öğrencilere örnekler sunacak şekilde yapılandırılmalarıdır (Root-Bernstein, 2015).

Maslow'un ihtiyaçlar teorisine göre kendini gerçekleştirme söz konusu olduğunda müzik anlayışı ve idrak edebilmeye yönelik uygulamalar, potansiyel bir aktivite olarak insanlara sunulabilir. Bu bağlamda, özel yetenekli öğrencilerin kendini gerçekleştirmesinde müzik takdirinin (müzik anlayışı ve idrakı) nasıl bir rol oynayabileceği, müzikal uygulamaların özel yetenekli öğrencilerin kendilerini gerçekleştirme ihtiyaçlarını karşılamaya nasıl dönüştürülebileceği düşünülmelidir (Piragasam vd., 2013).

$\mathrm{Bu}$ sebeple, özel eğitime ihtiyacı olan öğrencilere uygulanan çalışma planında, genellikle çocuğun kendisinin gerçekleştireceği, duygu ve düşüncelerini ortaya koyabileceği etkinliklere yer verilmesi gerekmektedir (müzik ve resim gibi) (Özsoy vd.,1994: 213). 
Akademik olarak üstün zekâlı ve yetenekli öğrencilere uygulanan niteliği farklılaştırılmış bir müfredatın parçası olarak müzik öğretimi (müzik öğretmenleri perspektifinden) ve öğreniminin (öğrencilerin perspektifinden) faydalı olduğunu ve üretkenliği beslediği ortaya konmaktadır. Müzik öğretmenlerinin; özel yetenekli öğrencilerin belirli öğrenme ihtiyaçlarını ve sosyal özelliklerini bilmelerin yanında, bu özel alandaki eğitim programları ve uygulamaları konusunda farkındalıklarını arttırarak mümkün olan en etkili müzik öğretimi yöntemleri ile aktif olarak ilgilenmeleri, müzik öğretimi ve öğreniminin kalitesi için olumlu olmaktadır. Ancak müzik eğitim programlarının kalitesini zaman ve kaynak açısından getirilen kısıtlamalar etkilemektedir. Müfredat dışı müzik derslerinde başarılı olmaya itilen öğrencilerin konuyla ilgili motivasyonlarını yitirdikleri ve müzik öğrenmeyi baskı ve ölçülebilir başarı ile ilişkilendirdikleri bildirilmektedir (Clarke \& Rowley, 2008).

Clarke'ın (2006) yaptığı araştırmada, akademik olarak özel yetenekli öğrenciler için kaliteli eğitim programları sağlamadaki temel faktörlerden birinin, öğrenme ihtiyaçları ve sosyal özellikleri hakkındaki farkındalık olduğunu belirtmiştir. Araştırma sonuçları dikkate değerdir. Bilişsel olarak özel yetenekli öğrencilerin müzik eğitimine kolaylıkla uyum sağlayamadıklarını, bu öğrencilerin hepsinin müzik konusunda yetenek veya ilgi geliştirmeyeceğinin kabul edilmesi gerektiğini, ancak öğrencilerin enstrüman çalmak, beste yapmak ve izleyici için performans sergilemeye güdülenmesi gibi etkinliklerle daha motive olduklarını ve bu bulguların kaliteli müzik eğitimi felsefelerine ilişkin literatürle uyumlu olduğunu belirtmiştir. Müzik eğitiminin ortaya çıkan iki rolünü vurgulamıştır; rekabetçi olma eğiliminde olan eğitim ortamındaki özel yetenekli öğrencilerin arasında, akran etkileşimini teşvik eden "eşitleyici" rolü ve öğrencileri eğlenceli bir şekilde motive etme değeri. Bunun önemli bir sonuç olmasının sebebi, olumlu sosyal, duygusal ve eğitimsel etkinlikleri nedeniyle akademik olarak da müzik eğitiminin, öğrencileri beslemesinin doğrulanmasıdır (Clarke, 2006: 60,62,71,72).

Müziğin çeşitli alanlarını müzik eğitiminde birbiri ile ilişkilendirerek ve bütünleştirerek yapılacak olan ders planlaması, mantıklı ve anlamlı bir öğrenme deneyimi sağlar. Özel yetenekli öğrencilere kapsamlı müzisyenlik ilkelerinden yararlanarak verilecek uygulamalı müzik dersi modeli beş kategoriden oluşmaktadır: kavramlar (tını, ritim, armoni, form, melodi, tonlama ve doku), içerik (müzik teorisi, müzik tarihi, müzik edebiyatı / tarzı, kulak eğitimi, kompozisyon teknikleri, doğaçlama teknikleri performans uygulamaları ve müzik estetiği), aktiviteler (performans, yaratıcılık, müziği yönetme/ şeflik, analitik dinleme ve tartışma), öğretim literatürü ve değerlendirme (Heavner, 2005).

Yapılan araştırmalar göz önünde bulundurulduğunda, müzik öğretmenlerinin özel yetenekli öğrencilerin bireysel farklılıklarını ele alması ve eğitim-öğretim programını bu öğrencilere uygun olarak planlanması gerekliliği doğmaktadır.

Öğrenci başarısını önemli ölçüde artıracak bir müfredat geliştirirken güçlü öğretmen katılımı da önemlidir. Öğretmenler, müfredat geliştirme konumunda olmasalar bile, pedagojik stratejileri ve müfredatın temel bileşenlerini uygulayabilirler. Tüm öğrenciler için en uygun öğrenme, öğretmenlerin yüksek kaliteli müfredat materyalleri kullanmasını ve üst düzey becerilere odaklanan öğretim uygulamasını gerektirir (Chandler, 2015). Özel yetenekli öğrencilerin hepsi sanatçı değildir. Bu sebeple müzik eğitimcileri, bilişsel süreçleri akranlarından önemli ölçüde farklı olan öğrencilerin ihtiyaçlarını karşılamanın yollarını bulmak durumundadırlar (Atterbury, 1990: 69).

Çalışma, toplumda özel yetenekleri ile farklılaşan ve sosyalleşmekte güçlük çektiği düşünülen üstün zekâlı ve üstün yetenekli çocukların, yardımcı bir araç olarak müzik eğitiminden faydalanılarak sosyal becerilerinin arttırılması yönünde bir fayda sağlanıp sağlanamayacağı üzerine kurgulanmıştır. 
Özel eğitime ihtiyaç duyan özel yetenekli öğrencilerin eğitim müfredatlarında yer alan genel müzik eğitimi ile müfredat dışında müzik eğitimi gören ve müzikal olarak yetenekli oldukları tespit edilen öğrencilere verilen eğitimlerin farkının altının çizilmesi ve eğitim programlarına sosyal beceri eğitmine yönelik etkinliklerin vurgulanması önemlidir. Eğitim sistemi içerisinde özel yetenekli çocuklara yönelik fayda sağlayıcı programların oluşturulması ve eğitim sistemine olumlu katkılar sunulabilecek olması yönü, bu araştırmanın önemini ortaya koymaktadır.

$\mathrm{Bu}$ araştırmanın problemi; "Müzik eğitiminin özel yetenekli öğrencilerin sosyal becerilerinin gelişimine etkisi var mıdır?" sorusu üzerinedir.

Araştırmanın test edilen hipotezleri şunlardır:

Hipotez 1: Deney ve kontrol grubunun Öntest puanları arasında fark yoktur. (T1=T2)

Hipotez 2: Deney grubu Öntest ve Sontest puanları arasında sontest lehine fark vardır. (T3>T1)

Hipotez 3: Kontrol grubu Öntest ve Sontest puanları arasında fark yoktur. (T4=T2)

Hipotez 4: Deney grubu ve kontrol grubu Sontest puanları arasında deney grubu lehine fark vardir. $(\mathrm{T} 3>\mathrm{T} 4)$

\section{Yöntem}

$\mathrm{Bu}$ araştırmada üstün zekâlı ve yetenekli çocukların sosyal duygusal uyumunda ve sosyal becerilerinin gelişiminde müzik eğitiminin etkilerini incelemek amacıyla yarı deneysel modelde, çalışma grubuna ait ait öntest- sontest kontrol gruplu seçkisiz desen (The randomized protesposttest control group design) kullanılmıştır.

Araştırmanın çalışma grubunu (N=18), İstanbul ilinde özel bir eğitim kurumunun Üstün Yetenekliler Eğitim Programı (ÜYEP), ilköğretim 2. sınıfta öğrenim gören öğrenciler oluşturduğu için araştırma modeli yarı deneysel yöntemdir. Bu desen, deney ve kontrol grupları benzer olabilen tam sinıflar şeklinde bir araya getirilen gruplar olduğu zaman sınıf deneylerinde siklıkla kullanılmaktadır ( Best \& Kahn, 2017: 200). Ancak; daha önceden rastgele atama dişında bir yolla oluşturulmuş gruplar rastgele deney ve kontrol grubu olarak belirlenir (Çepni, 2005:53). Araştırma grubu, yansız atama yöntemiyle (random) deney $(n=9)$ ve kontrol $(n=9)$ grupları oluşturulmuştur ve her iki grubun yaş ortalaması 94 aydır ( 7 yıl 10 ay).

Öntest- sontest kontrol gruplu seçkisiz desenlerde, deney ve kontrol grubunun uygulama öncesinde bağımlı değişkenle ilgili ölçümleri alınır. Uygulama sürecinde etkisi test edilen deneysel işlem deney grubuna verilirken kontrol grubuna verilmez. Son olarak gruplardaki deneklerin bağımlı değişkene ait ölçümleri aynı araç ya da eş formu kullanılarak tekrar elde edilir (Büyüköztürk, Kılıç, Akgün, Karadeniz, 2009: 201-202). Buna göre, desenin simgesel gösterimi Tablo 2'de verilmiştir.

Tablo 2: Öntest-Sontest Kontrol Gruplu Desen

\begin{tabular}{lllll}
\hline $\mathrm{R}$ & $\mathrm{G} 1$ & $\mathrm{~T} 1$ & $\mathrm{X}$ & $\mathrm{T}$ \\
\hline $\mathrm{R}$ & $\mathrm{G} 2$ & $\mathrm{~T} 2$ & & $\mathrm{~T} 4$ \\
\hline
\end{tabular}

Desendeki " $R$ " grupların oluşturulmasındaki yansızlık ilkesini, "G1” Deney grubunu, "G2” Kontrol grubunu, " $X$ ” Bağımsız değişken düzeyini, " $T$ ” yapılan (öntest-sontest) ölçümleri temsil etmektedir.

Deney grubuna etkililiği test edilmek üzere zenginleştirilerek hazırlanmış bir öğretim programı uygulanırken, kontrol grubuna Milli Eğitim Bakanlığının Müfredatına göre planlanan müzik öğretim programı uygulanmıştır. Programın uygulanmasından sonra, deney grubundaki farklılığ 1 görmek üzere kontrol grubuyla karşılaş̧tırılmıştır.

Araştırma kapsamında, 12 hafta süresince haftada 1 saat zenginleştirilmiş müzik eğitimi programı ile haftada 1 saat MEB müzik öğretimi programı deney grubuna uygulanmıştır. Deney grubu ile yapılan uygulama süresince gözlem yapılmış ve elde edilen veriler değerlendirilmiştir. 
Deney grubuna çalg1 eğitiminden ziyade öğrencilerin beden ve seslerini kullanabildikleri, grup çalışması, müzikal ve ritmik oyunların ağırlıkta olduğu içeriğe sahip zenginleştirilmiş müzik öğretimi programı uygulanmıştır. Kontrol grubuna ise, sadece var olan MEB müzik öğretimi programı haftada 2 saat uygulanmıştır. Her iki grupta deney öncesi ve deney sonrası ölçmeler yapılmıştır.

Araştırmada, Akçamete ve Avcıŏglu (2005)'nun geliştirdiği Sosyal Becerileri Değerlendirme Ölçeği (SBDÖ, 7-12 Yaş) kullanılmıştır. Bu ölçek, sosyal etkileşimi arttırmak için iletişim yetersizliklerine yardım etmede önemli olan becerileri ölçmeyi amaçlamaktadır ve beşli dereceleme şeklinde oluşturulmuş likert tipi bir ölçektir. SBDÖ, 7 ile 12 yaşlarındaki çocukların sahip olması gereken sosyal becerileri içermektedir. 69 maddeden oluşan ölçekte beceriler 12 kategori altında toplanmıştır. Alt Ölçekler; Temel Sosyal Beceriler (TSB), Temel Konuşma Becerileri (TKB) 4, İleri Konuşma Becerileri (IKB) 5, İlişkiyi Başlatma Becerileri (İBB), İlişkiyi Sürdürme Becerileri (İSB), Grupla İş Yapma Becerileri (GIYB), Duygusal Beceriler (DB), Kendini Kontrol Etme Becerileri (KKEB), Saldırgan Davranışlarla Başa Çıkma Becerileri (SDBÇB), Sonuçları Kabul Etme Becerileri (SKEB), Yönerge Verme Becerileri (YVB) ve Bilişsel Beceriler (BB)'i oluşturan maddelerden oluşmaktadır. Maddelerin tamamı olumlu yönde düzenlenmiştir. Düşük puan, sosyal becerilere yeterince sahip olunmadığını, yüksek puan ise sosyal becerilere sahip olunduğunu göstermektedir. Sosyal Becerileri Değerlendirme Ölçeği (7-12 Yaş) (SDBÖ) Cronbach alfa katsayısı toplam $.98^{\prime}$ dir. Hem alt ölçekler hem de testin bütününe ilişkin elde edilen Cronbach alfa katsayılarının oldukça yüksek olduğu görülmektedir (Akçamete \& Avcıoğlu, 2005).

İstatistiksel değerlendirme SPSS 18.0 (SPSS Inc., Chicago, IL, USA) programı kullanılarak yapılmıştır. Yaş ve Sosyal Becerileri Değerlendirme Ölçeği (7-12 Yaş) için alt boyutlar bakımından iki grubun karşılaştırılmasında parametrik test varsayımları sağlanamadığından MannWhitney U testi kullanılmıştır.

Deney ve kontrol gruplarının Sosyal Becerileri Değerlendirme Ölçeği (7-12 Yaş) için öntest ve sontest puanlarının karşılaştırılmasında Wilcoxon eşleştirilmiş iki örnek testinden faydalanılmıştır.

Kullanılan bu yöntem parametrik olmayan bir yöntem olduğu için ortanca ve yaygınlık ölçüsü olarak standart sapma yerine minimum ve maksimum değerler dikkate alınmalıdır (Akdağ ve Sümbüloğlu, 2011:160). Sayısal değişkenler için tanımlayıcı istatistikler ortalama \pm standart sapma ve ortanca (minimum-maksimum), kategorik yapıdaki veriler için sayı ve yüzde olarak ifade edilmiştir.

\section{Bulgular \\ Bulgu I: Deney ve Kontrol Grubu Arasındaki Sosyal Beceri Düzeyleri Öntest Verilerinin Karşılaştırılması}

Araştırmanın ilk hipotezi deney ve kontrol grubu arasında sosyal becerileri düzeylerinde fark olmadığını bulmaya yöneliktir.

Hipotez 1: Deney ve kontrol grubunun Öntest puanları arasında fark yoktur. (T1=T2) 
Tablo 3: Deney ve Kontrol Grubunun Öntest Verilerinin Mann- Whitney U Testi ile Karşılaştırılması

\begin{tabular}{lccccc}
\hline \multicolumn{1}{c}{ Sosyal Becerileri Değerlendirme Ölçeği } & $\begin{array}{c}\text { Deney } \\
\mathbf{n}=\mathbf{9} \\
\text { Ortanca } \\
\text { (min-max) }\end{array}$ & $\begin{array}{c}\text { Kontrol } \\
\mathbf{n = 9} \\
\text { Ortanca } \\
\text { (min-max) }\end{array}$ & $\mathbf{u}$ & $\mathbf{z}$ & $\mathbf{p}$ \\
\hline Temel Sosyal Beceriler (TSB) & $55(50-60)$ & $57(51-64)$ & 37.00 & -0.311 & 0.796 \\
\hline Temel Konuşma Becerileri (TKB) & $17(16-20)$ & $17(13-20)$ & 36.50 & -0.378 & 0.730 \\
\hline İleri Konuşma Becerileri (IKB) & $22(19-24)$ & $21(18-25)$ & 32.00 & -0.758 & 0.489 \\
\hline İlişkiyi Başlatma Becerileri (IBB) & $20(18-25)$ & $23(20-24)$ & 23.00 & -1.562 & 0.136 \\
\hline İlişkiyi Sürdürme Becerileri (ISB) & $26(24-29)$ & $26(21-29)$ & 36.00 & -0.402 & 0.730 \\
\hline Grupla İş Yapma Becerileri (GIYB) & $32(27-35)$ & $33(28-35)$ & 34.50 & -0.537 & 0.605 \\
\hline Duygusal Beceriler (DB) & $26(24-30)$ & $28(24-30)$ & 32.50 & -0.715 & 0.489 \\
\hline Kendini Kontrol Etme Becerileri (KKEB) & $26(21-28)$ & $26(22-30)$ & 30.50 & -0.905 & 0.387 \\
\hline $\begin{array}{l}\text { Saldırgan Davranışlarla Başa Çıkma } \\
\text { Becerileri (SDBÇB) }\end{array}$ & $17(14-20)$ & $17(16-18)$ & 28.50 & -1.097 & 0.297 \\
\hline Sonuçları Kabul Etme Becerileri (SKEB) & $15(9-15)$ & $12(10-15)$ & 28.50 & -1.113 & 0.297 \\
\hline Yönerge Verme Becerileri (YVB) & $20(14-20)$ & $19(16-20)$ & 33.00 & -0.698 & 0.546 \\
\hline Bilişsel Beceriler (BB) & $26(24-28)$ & $27(25-30)$ & 29.00 & -1.042 & 0.340 \\
\hline
\end{tabular}

Tablo 3'e göre Deney ve kontrol grubunun Öntest verileri karşılaştırıldığında, Sosyal Becerileri Değerlendirme Ölçeği (7-12 yaş) alt boyut (TSB, TKB, İKB, İSB, GIYYB, DB, KKEB, SDBÇB, SKEB, YVB, BB) puanları arasında anlamlı bir farklılık bulunamamıştır.

\section{Bulgu II: Deney Grubu Sosyal Beceri Düzeyleri Öntest- Sontest Verilerinin}

\section{Karşılaştırılması}

Araştırmanın ikinci hipotezi deney grubunun öntest ve sontest puanları arasında sontest lehine fark olduğunu araştırmaya yöneliktir. (T3>T1)

Hipotez 2: Deney grubu Öntest ve Sontest puanları arasında sontest lehine fark vardır. 
Tablo 4: Deney Grubunun Öntest ve Sontest Puanlarının Wilcoxon Eşleştirilmiş İki Örnek Testi İle Karşışaştırılması

\begin{tabular}{lcccc}
\hline \multicolumn{1}{c}{$\begin{array}{c}\text { Sosyal Becerileri Değerlendirme Ölçeği } \\
\text { (7-12 Yaş) }\end{array}$} & $\begin{array}{c}\text { Öntest } \\
\text { Ortanca } \\
\text { (min-max) }\end{array}$ & $\begin{array}{c}\text { Sontest } \\
\text { Ortanca } \\
\text { (min-max) }\end{array}$ & z & p \\
\hline Temel Sosyal Beceriler (TSB) & $55(50-60)$ & $65(64-65)$ & -2.670 & $\mathbf{0 . 0 0 8 *}$ \\
\hline Temel Konuşma Becerileri (TKB) & $17(16-20)$ & $20(20-20)$ & -2.070 & $\mathbf{0 . 0 3 8}^{*}$ \\
\hline İleri Konuşma Becerileri (İKB) & $22(19-24)$ & $25(14-25)$ & -1.604 & 0.109 \\
\hline İlişkiyi Başlatma Becerileri (IBBB) & $20(18-25)$ & $25(25-25)$ & -2.530 & $\mathbf{0 . 0 1 1 ^ { * }}$ \\
\hline İlişkiyi Sürdürme Becerileri (ISB) & $26(24-29)$ & $28(27-30)$ & -1.897 & 0.058 \\
\hline Grupla İş Yapma Becerileri (GIYB) & $32(27-35)$ & $35(32-35)$ & -2.201 & $\mathbf{0 . 0 2 8 *}$ \\
\hline Duygusal Beceriler (DB) & $26(24-30)$ & $30(30-30)$ & -2.533 & $\mathbf{0 . 0 1 1 ^ { * }}$ \\
\hline Kendini Kontrol Etme Becerileri (KKEB) & $26(21-28)$ & $30(30-30)$ & -2.689 & $\mathbf{0 . 0 0 7 *}$ \\
\hline $\begin{array}{l}\text { Saldırgan Davranışlarla Başa Çıkma Becerileri } \\
\text { (SDBÇB) }\end{array}$ & $17(14-20)$ & $18(17-19)$ & -1.706 & 0.088 \\
\hline Sonuçları Kabul Etme Becerileri (SKEB) & $15(9-15)$ & $15(14-15)$ & -1.604 & 0.109 \\
\hline Yönerge Verme Becerileri (YVB) & $20(14-20)$ & $20(20-20)$ & -1.841 & 0.066 \\
\hline Bilişsel Beceriler (BB) & $26(24-28)$ & $30(30-30)$ & -2.684 & $\mathbf{0 . 0 0 7 *}$ \\
\hline
\end{tabular}

Tablo 4'e göre Deney grubu öntest ve sontest puanları karşılaştırıldığında Sosyal Becerileri Değerlendirme Ölçeği (7-12 yaş) alt boyutları arasında yer alan;

Temel Sosyal Beceriler (TSB) sontest puanı öntest puanından 0.008 düzeyinde istatistiksel olarak anlamlı derecede yüksek bulunmuştur.

Temel Konuşma Beceriler (TKB) sontest puanı öntest puanından 0.038 düzeyinde istatistiksel olarak anlamlı derecede yüksek bulunmuştur.

İlişkiyi Başlatma Beceriler (İBB) sontest puanı öntest puanından 0.011 düzeyinde istatistiksel olarak anlamlı derecede yüksek bulunmuştur.

Grupla İş Yapma Beceriler (GIYB) sontest puanı öntest puanından 0.028 düzeyinde istatistiksel olarak anlamlı derecede yüksektir.

Duygusal Beceriler (DB) sontest puanı öntest puanından 0.011 düzeyinde istatistiksel olarak anlamlı derecede yüksek bulunmuştur.

Kendini Kontrol Etme Beceriler (KKEB) sontest puanı öntest puanından 0.007 düzeyinde istatistiksel olarak anlamlı derecede yüksek bulunmuştur.

Bilişsel Beceriler (BB) sontest puanı öntest puanından 0.007 düzeyinde istatistiksel olarak anlamlı derecede yüksek bulunmuştur. 


\section{Bulgu III: Kontrol Grubu Sosyal Beceri Düzeyleri Öntest- Sontest Verilerinin Karşılaştırılması}

Araştırmanın üçüncü hipotezi kontrol grubunun öntest ve sontest puanları arasında sontest lehine fark olmadığını araştırmaya yöneliktir.

Hipotez 3: Kontrol grubu öntest ve sontest puanları arasında fark yoktur. (T4=T2)

Tablo 5: Kontrol Grubunun Öntest Ve Sontest Puanlarının Wilcoxon Eşleştirilmiş İki Örnek Testi İle

\begin{tabular}{lcccc}
\multicolumn{1}{c}{ Sosyal Becerileri Değerlendirme Ölçeği } \\
$(\mathbf{7 - 1 2}$ Yaş) & $\begin{array}{c}\text { Öntest } \\
\text { Ortanca } \\
\text { (min-max) }\end{array}$ & $\begin{array}{c}\text { Sontest } \\
\text { Ortanca } \\
(\mathbf{m i n}-\mathbf{m a x})\end{array}$ & $\mathbf{z}$ & p \\
\hline Temel Sosyal Beceriler (TSB) & $57(51-64)$ & $63(47-65)$ & -2.320 & $\mathbf{0 . 0 2 0 *}$ \\
\hline Temel Konuşma Becerileri (TKB) & $17(13-20)$ & $20(16-20)$ & -1.841 & 0.066 \\
\hline İleri Konuşma Becerileri (İKB) & $21(18-25)$ & $24(20-25)$ & -1.275 & 0.202 \\
\hline İlişkiyi Başlatma Becerileri (İBB) & $23(20-24)$ & $25(20-25)$ & -1.973 & $\mathbf{0 . 0 4 9 *}$ \\
\hline İlişkiyi Sürdürme Becerileri (İSB) & $26(21-29)$ & $28(24-29)$ & -2.404 & $\mathbf{0 . 0 1 6 *}$ \\
\hline Grupla İş Yapma Becerileri (GİYB) & $33(28-35)$ & $35(28-35)$ & -1.892 & 0.058 \\
\hline Duygusal Beceriler (DB) & $28(24-30)$ & $30(24-30)$ & -1.367 & 0.172 \\
\hline Kendini Kontrol Etme Becerileri (KKEB) & $26(22-30)$ & $30(23-30)$ & -0.136 & 0.892 \\
\hline Saldırgan Davranışlarla Başa Çıkma Becerileri (SDBÇB) & $17(16-18)$ & $18(15-20)$ & -0.412 & 0.680 \\
\hline Sonuçları Kabul Etme Becerileri (SKEB) & $12(10-15)$ & $15(11-15)$ & -2.379 & $\mathbf{0 . 0 1 7 *}$ \\
\hline Yönerge Verme Becerileri (YVB) & $19(16-20)$ & $20(19-20)$ & -2.032 & $\mathbf{0 . 0 4 2 *}$ \\
\hline Bilişsel Beceriler (BB) & $27(25-30)$ & $30(28-30)$ & -2.536 & $\mathbf{0 . 0 1 1 *}$ \\
\hline
\end{tabular}

Tablo 5'e göre kontrol grubu öntest ve sontest puanları karşılaştırıldığında Sosyal Becerileri Değerlendirme Ölçeği (7-12 yaş) alt boyutları arasında yer alan;

Temel Sosyal Beceriler (TSB) sontest puanı öntest puanından 0.020 düzeyinde istatistiksel olarak anlamlı derecede yüksek bulunmuştur.

İlişkiyi Başlatma Beceriler (İBB) sontest puanı öntest puanından 0.049 düzeyinde istatistiksel olarak anlamlı derecede yüksek bulunmuştur.

İlişkiyi Sürdürme Becerileri (ISB) sontest puanı öntest puanından 0.016 düzeyinde istatistiksel olarak anlamlı derecede yüksek bulunmuştur.

Sonuçları Kabul Etme Becerileri (SKEB) sontest puanı öntest puanından 0.017 düzeyinde istatistiksel olarak anlamlı derecede yüksek bulunmuştur.

Yönerge Verme Becerileri (YVB) sontest puanı öntest puanından 0.042 düzeyinde istatistiksel olarak anlamlı derecede yüksek bulunmuştur.

Bilişsel Beceriler (BB) sontest puanı öntest puanından 0.011 düzeyinde istatistiksel olarak anlamlı derecede yüksek bulunmuştur. 


\section{Bulgu IV: Deney ve Kontrol Grubu Arasındaki Sontest Verilerinin Karşılaştırılması}

Araştırmanın dördüncü hipotezi deney grubu ve kontrol grubu sontest puanları arasında deney grubu lehine fark olduğunu araştırmaya yöneliktir.

Hipotez 4: Deney grubu ve kontrol grubu sontest puanları arasında deney grubu lehine fark vardir. (T3>T4)

Tablo 6: Deney ve Kontrol Grubunun Sontest Verilerinin Mann- Whitney U Testi ile Karşılaştrılması

\begin{tabular}{lccccc}
\hline $\begin{array}{l}\text { Sosyal Becerileri Değerlendirme Ölçeği } \\
\text { (7-12 Yaş) }\end{array}$ & $\begin{array}{c}\text { Deney } \\
\mathbf{n = 9} \\
\text { Ortanca } \\
\text { (min-max) }\end{array}$ & $\begin{array}{c}\text { Kontrol } \\
\mathbf{n = 9} \\
\text { Ortanca } \\
\text { (min-max) }\end{array}$ & $\mathbf{u}$ & $\mathbf{z}$ & $\mathbf{p}$ \\
\hline Temel Sosyal Beceriler (TSB) & $65(64-65)$ & $63(47-65)$ & 27.00 & -1.605 & 0.161 \\
\hline Temel Konuşma Becerileri (TKB) & $20(20-20)$ & $20(16-20)$ & 36.00 & -1.000 & 0.730 \\
\hline İleri Konuşma Becerileri (IKB) & $25(14-25)$ & $24(20-25)$ & 28.50 & -1.207 & 0.297 \\
\hline İlişkiyi Başlatma Becerileri (İBB) & $25(25-25)$ & $25(20-25)$ & 27.00 & -1.835 & 0.258 \\
\hline İlişkiyi Sürdürme Becerileri (İSB) & $28(27-30)$ & $28(24-29)$ & 28.00 & -1.185 & 0.297 \\
\hline Grupla İş Yapma Becerileri (GIYB) & $35(32-35)$ & $35(28-35)$ & 40.00 & -0.081 & 1.000 \\
\hline Duygusal Beceriler (DB) & $30(30-30)$ & $30(24-30)$ & 27.00 & -1.835 & 0.258 \\
\hline Kendini Kontrol Etme Becerileri (KKEB) & $30(30-30)$ & $30(23-30)$ & 22.50 & -2.184 & 0.113 \\
\hline $\begin{array}{l}\text { Saldırgan Davranışlarla Başa Çıkma } \\
\text { Becerileri (SDBÇB) }\end{array}$ & $18(17-19)$ & $18(15-20)$ & 32.50 & -0.745 & 0.489 \\
\hline Sonuçları Kabul Etme Becerileri (SKEB) & $15(14-15)$ & $15(11-15)$ & 35.00 & -0.748 & 0.666 \\
\hline Yönerge Verme Becerileri (YVB) & $20(20-20)$ & $20(19-20)$ & 36.00 & -1.000 & 0.730 \\
\hline Bilişsel Beceriler (BB) & $30(30-30)$ & $30(28-30)$ & 27.00 & -1.837 & 0.258 \\
\hline
\end{tabular}

Tablo 6'ya göre Deney ve kontrol grubunun Öntest verileri karşılaştırıldığında, Sosyal Becerileri Değerlendirme Ölçeği (7-12 yaş) alt boyut (TSB, TKB, İKB, İSB, GIYY, DB, KKEB, SDBÇB, SKEB, YVB, BB) puanları arasında istatiksel olarak anlamlı bir farklılık bulunamamıştır.

\section{Sonuç, Tartışma ve Öneriler}

\section{Bulgu I ile İlgili Sonuçlar}

Araştırmanın ilk bulgusu ile ilgili analizlerin sonucuna göre deney ve kontrol grubu arasında sosyal beceri düzeyleri arasında fark yoktur. Deney ve kontrol grubunun Öntest verileri karşılaştırıldığında, Sosyal Becerileri Değerlendirme Ölçeği (7-12 yaş) alt boyut (TSB, TKB, IKKB, İSB, GIYB, DB, KKEB, SDBÇB, SKEB, YVB, BB) puanları arasında anlamlı bir farklılık yoktur.

\section{Bulgu II ile İlgili Sonuçlar}

Araştırmanın ikinci hipotezi ilgili analizlerin sonucuna göre deney grubunun öntest ve sontest puanları arasında sontest lehine fark vardır. Deney öntest ve sontest puanları karşılaştırıldığında Sosyal Becerileri Değerlendirme Ölçeği (7-12 yaş) alt boyutları sontest 
sonuçları öntest sonuçlarına göre daha yüksektir. Temel Sosyal Beceriler (TSB), Temel Konuşma Becerileri (TKB), İlişkiyi Başlatma Becerileri (IBB), Grupla İş Yapma Becerileri (GiYYB), Duygusal Beceriler (DB), Kendini Kontrol Etme Becerileri (KKEB) ve Bilişsel Beceriler (BB) sontest puanı öntest puanından yüksektir.

\section{Bulgu III ile İlgili Sonuçlar}

Araştırmanın üçüncü hipotezi ilgili analizlerin sonucuna göre kontrol grubunun Temel Sosyal Beceriler (TSB), İlişkiyi Başlatma Beceriler (IBBB), İlişkiyi Sürdürme Becerileri (İSB), Sonuçları Kabul Etme Becerileri (SKEB), Yönerge Verme Becerileri (YVB) ve Bilişsel Beceriler (BB) sontest puanları öntest puanından yüksektir.

\section{Bulgu IV ile İlgili Sonuçlar}

Araştırmanın dördüncü hipotezi ilgili analizlerin sonucuna göre Deney ve kontrol Sosyal Becerileri Değerlendirme Ölçeği (7-12 yaş) TSB, TKB, IKKB, İSB, GİYB, DB, KKEB, SDBÇB, SKEB, YVB, BB düzeyleri arasında olarak anlamlı bir farklılık yoktur.

\section{Tartışma}

Araştırmanın ilk bulgusu, deney ve kontrol grubunun Öntest sonuçları incelendiğinde; temel sosyal, duygusal ve bilişsel becerilerde, temel konuşma, ilişkiyi başlatma ve sürdürme, grupla iş yapma, kendini kontrol etme, saldırgan davranışlarla başa çıkma, sonuçları kabul etme ve yönerge verme becerileri karşılaştırıldığında; deney ve kontrol gurubunun dağılımının homojen olduğu görülmüştür. Deney ve kontrol grubu arasında sosyal beceri düzeyleri arasında fark olmaması beceri düzeyleri açısından her iki grubun da (deney ve kontrol grubu) eşit şartlarda uygulamaya başlamış olduğunu doğrulamaktadır. Deneysel yöntemde, gruplar oluşturulurken dikkat edilmesi gereken en önemli husus, deney ve kontrol gruplarının mümkün olduğunca eşdeğer gruplar olması gereğidir (Çepni, 2005:53).

Öğrenciler hakkındaki tanımlayıcı tüm veriler zekâyı, sosyal uyumu, sosyal becerileri ve gelişimi etkilediği düşünülürse, her iki grubun da eşit şartlarda uygulamaya başladığını tespit etmek araştırmanın güvenirliği açısından önemlidir. Ancak daha da önemlisi uygulama öncesi sosyal becerileri değerlendirmelerinde deney ve kontrol grubunun birbirinden farkı olmadığının tespitidir.

Araştırmanın ikinci bulgusu ile ilgili sonuçlar incelendiğinde; Deney öntest ve sontest puanları karşılaştırıldığında Sosyal Becerileri Değerlendirme Ölçeği (7-12 yaş) alt boyutlarında (Temel Sosyal Beceriler, Temel Konuşma Becerileri, İlişkiyi Başlatma Becerileri, Grupla İş Yapma Becerileri, Duygusal Beceriler, Kendini Kontrol Etme Becerileri ve Bilişsel Beceriler), sontest puanının öntest puanından yüksek olduğu, analizlerin sonucuna göre deney grubunun öntest ve sontest puanları arasında sontest lehine fark olduğu görülmüştür. Bu sonuç, zenginleştirilmiş müzik eğitimi programı ile yapılan uygulamanın deney grubunda etkili olduğunu göstermektedir.

Deney grubu ile yapılan uygulamada uygulanan eğitim programında, enstrüman ile değil kendi bedeni ile katılacağı etkinliklere, grup çalışması içinde arkadaşları ile keyif alacağı oyunlara, yaşantısında yer açacak ve günlük yaşantılarında kullanacak bilgilere ağırlık verilmiştir. Bu sebeple, öğrencilerin sosyal becerilerinin gelişiminin pozitif yönde etkilendiği düşünülmektedir.

Özmenteş ve Bilen (2005), çalışmalarında deney grubu ile müziksel öğeleri beden hareketleri aracılığıyla çalışırken; kontrol grubu ise bedensel hareket içerikli herhangi bir eğitim almamış, geleneksel şarkı söyleme, nota yazma ve temel müzik bilgilerini öğrenme etkinlikleri almışlardır. Araştırmalarında uyguladıkları çalışmanın, geleneksel müzik öğretimine göre daha etkili olduğu sonucuna ulaşmışlardır. Araştırma sonucunun, bu çalışmanın verileri ile benzerlik gösterdiği görülmektedir (Özmenteş ve Bilen,2005).

Başer (2015) ise toplu müzik çalışmalarının öğrencilerin arkadaşlarıyla birlikte bir iş yapma, düzenli ve disiplinli olma, sırasının gelmesini bekleme, sabretme gibi sosyal hayatın gereği 
olan alışkanlıklar kazandırdığını ve kümede şarkı söylerken sesini kullanmayı, yanındaki arkadaşlarını ve diğerlerini dinleyerek sesini denetlemeyi öğrendiğini belirtmiştir (Başer, 2015).

Araştırmanın üçüncü bulgusu ile ilgili sonuçlar incelendiğinde; Kontrol grubunun Temel Sosyal Beceriler (TSB), İlişkiyi Başlatma Becerileri (IBB), İlişkiyi Sürdürme Becerileri (ISSB), Sonuçları Kabul Etme Becerileri (SKEB), Yönerge Verme Becerileri (YVB) ve Bilişsel Beceriler (BB) sontest puanlarının da öntest puanlarından yüksek olduğu görülmektedir.

Kontrol grubunda pozitif yönde gelişen sosyal beceriler, müzik eğitimin faydaları adına olumlu bir sonuçtur. Kontrol grubunun da öntest ve sontest puanları arasında sontest lehine fark olduğu sonucuna göre, içinde çocukların birçok alanda gelişmesini ön planda tutan MEB müzik dersi müfredatına göre yapılan müzik eğitiminin de etkili olduğu düşünülmektedir.

Güven (2017)'nin çalışmasında da çocukların müziğe ilişkin tutumları arttıkça sosyal beceri düzeylerinin de arttığı sonucuna varılması (Güven, 2017), bu çalışmanın verileri ile paralellik göstermektedir.

Kontrol grubuna da müzik eğitimi verildiği için sosyal becerilerinde pozitif yönde gelişme olması bulgusu normal kabul edilmiştir. Sadece deney grubuna müzik eğitimi verilip ve kontrol grubuna hiç müzik eğitimi verilmemiş olsayd1, istatistiksel bulgularda farklı sonuçlar elde edilebileceği düşünülebilirdi. Fakat bu olasılıktan yola çıkılarak öğrenciler üzerinde yapılacak olan bir araştırmanın, hem Anayasa'ya hem Milli Eğitim'in etiğine aykırı ayrıca insani bakımdan da haksızlık olacağı düşünülmektedir.

Tablo 7: Deney ve Kontrol Grubunda Gelişen Sosyal Becerilerin Karşılaştırılması

\begin{tabular}{ll}
\multicolumn{1}{c}{ Deney Grubu } & \multicolumn{1}{c}{ Kontrol Grubu } \\
\hline Temel Sosyal Beceriler (TSB)* & \multicolumn{1}{c}{ Temel Sosyal Beceriler (TSB) * } \\
Temel Konuşma Becerileri (TKB) & İlişkiyi Başlatma Becerileri (IBBB)* \\
İlişkiyi Başlatma Becerileri (İBB)* & İlişkiyi Sürdürme Becerileri (ISB) \\
Grupla İş Yapma Becerileri (GİYB) & Sonuçları Kabul Etme Becerileri (SKEB) \\
Duygusal Beceriler (DB) & Yönerge Verne Becerileri (YVB) \\
Kendini Kontrol Etme Becerileri (KKEB) & Bilişsel Beceriler (BB)* \\
Bilişsel Beceriler (BB)* & \\
\hline
\end{tabular}

Tablo 7' ye göre; Kontrol grubuna uygulanan programın, fark yaratmadığı sosyal beceri alt boyutları; Temel Konuşma Beceriler (TKB), Grupla İş Yapma Beceriler (GIYYB), Duygusal Beceriler (DB) ve Kendini Kontrol Etme Beceriler (KKEB) olarak görülmektedir

İki uygulama yönteminin ortak bulguları, Temel Sosyal Becerilerin (TSB), İlişkiyi Başlatma Becerileri (IBB) ve Bilişsel Becerilerin gelişimidir.

Bu beceri dışında, deney ve kontrol grubunda farklı alanlardaki sosyal beceriler gelişmiştir. Deney grubuna uygulanan müzik eğitiminin, İlişkiyi Sürdürme Becerileri (İSB) ve Sonuçları Kabul Etme Becerileri (SKEB) üzerinde bir fark yaratmadığg görülmektedir. Bunun sebebi olarak; deney grubuna uygulanan, yaparak, yaşayarak, oynayarak deneyimlemeye dayanan zenginleştirilmiş bu programın eksik noktalarının giderilmesi gerekliliğinden ve geliştirilmeye ihtiyacı olmasından kaynaklandığı düşünülebilir.

Araştırmanın dördüncü bulgusu ile ilgili sonuçlar incelendiğinde; Deney ve kontrol grubunun sontest verileri karşılaştırıldığında Sosyal Becerileri (TSB, TKB, İKB, İSB, GIYB, DB, KKEB, SDBÇB, SKEB, YVB, BB) düzeyleri arasında anlamlı bir farklılık olmadığı görülmektedir.

Deney ve kontrol grubunun sontest verileri karşılaştırıldığında sosyal beceri düzeyleri arasında anlamlı bir farklılık olmaması; kontrol edilemeyen değişkenlerden kaynaklanıyor olabilir. Araştırmada yer alan çalışma grubu, bulunduğu yaşa gelene kadar bazı sosyal becerileri kazanmış durumdadır. Araştırma yaşı daha küçük; 2. Sınıf öğrencileriyle değil de 1. Sınıf ya da anaokulu 
öğrencileriyle; ekonomik düzeyi düşük, sayı olarak fazla olan gruplarda yani farklı ortam, yaş, durumlarda uygulanırsa, sosyal beceri düzeylerinde farklı sonuçların elde edilebileceği düşünülmektedir.

Ayrıca sosyal becerilerinin gelişimine dair bu araştırmada yer alan sonuçların sebebinin, her iki guruba da aynı sürede, farklı yöntemlerle de olsa müzik eğitimi verilmiş olmasına bağlanabilir. Milli Eğitim Bakanlığı müfredatında belirlenen ve haftada 2 saat olan müzik dersinin 1 saatinde, her iki grup okulun müzik öğretmeniyle müzik dersi yaparken, yalnızca deney grubu diğer 1 saati araştırmacı ile uygulama yapmış; kalan 1 saati de okulun müzik öğretmeniyle müzik dersi yaparak sürdürmüştür. Oyun ve grup çalışması ağırlıklı yapılan müzik eğitimi programının sosyal becerilerin gelişiminde etkili ve faydalı olduğu düşünülmektedir. Ancak hem araştırmacı tarafindan zenginleştirilerek planlanan program hem de müfredata uygun olarak yürütülen programın yöntem farklılıklarının sosyal becerilerin farklı alanlarını geliştirdiği de araştırma sonuçlarında açıkça görülmektedir.

\section{Öneriler}

Araştırmanın, karma eğitim gören üstün yetenekli/zekâlı öğrenciler olarak tanımlanmış öğrenciler ile; ZB'leri (Zeka Bölümleri) normal olarak adlandırılan öğrencilerin arasındaki sosyal beceri düzeylerinin ölçülmesi önerilmektedir. Ortaya çıkacak sonuçların, üstün zekâlı/ yetenekli öğrencilerin sosyal beceri düzeylerinin hangi düzeyde olduğu konusunda başka bir bakış açısı sağlayabileceğine inanılmaktadır.

Araştırmada, deney grubunda yapılan uygulamanın etkili olduğunu görülmüştür. Ancak sosyal becerilerin tümünü geliştirememiştir. Deney grubuna uygulanan müzik eğitimi programının iyileştirilmesi ve eksikliklerin tamamlanması önerilmektedir. Aynı zamanda kontrol grubunda da sontest puanları lehine bir fark olması, kontrol grubuyla yürütülen müzik eğitimi programının da etkili olduğunu göstermektedir. Bulgu ve sonuçlara dayanarak; müzik eğitiminin, deney ve kontrol grubunda farklı alt boyutlardaki sosyal becerileri geliştirdiği göstergesine göre, eğitim sistemi içerisinde verilen müzik eğitimin özel yetenekli öğrencilere yönelik olarak da ayrıca ele alınması önerilmektedir.

Müzik eğitim yöntemleri hem her öğrenci için hem tek öğrenci içindir. Öğretmen, öğrencilerin bireysel farklılıkları, ihtiyaçları ve gereksinimlerini göz önünde bulundurarak hangi öğrenciye hangi yöntemin uygulanacağını titizlikle planlanmalıdır. Programın kendine verdiği esnekliği, öğrencilerin öğrenme stiline uygun olarak güdüleme, motive etme, problem çözme ve müzik eğitiminde uygulanan etkinlikler arasında denge sağlama yönünde kullanmalıdır. Öğretmen, müzik eğitiminin yapıldığı sınıfın psikolojik ve sosyal ortamını, öğrencilerin sosyal uyum düzeylerini arttırma ve sosyal duygusal becerilerini geliştirmeye elverişli olarak desteklemelidir. Müzik öğretmenlerinin bu çalışmaya konu olan özel öğrenciler kapsamında eğitim sürecinde aktif olmak adına mesleki güncellemelere ihtiyaç duyabileceği düşünülmektedir.

Müzik eğitim programının, sosyal becerilerinin gelişimine yönelik olarak yenilenmesi, üstün yetenekli/ zekâlı olarak tanımlanmış çocukların yeteneğini keşfetmek adına değil, genel eğitim- öğretimleri içerisinde müzik eğitimine olan ihtiyacına dayanarak müzik eğitim programlarının zenginleştirilmesi önerilmektedir.

Araştırmanın farklı ortam ve farklı koşullarda yapılması önerilmektedir. Araştırma, ilkokul ve anaokulu öğrencileri ve sosyo-ekonomik düzeyi düşük özel yetenekli çocuklar ile tekrar ele alınmalıdır.

Uluslararası ve ulusal eğitim sistemlerinde son yeniliklerin takip edilmesi, özel yetenekliler için uygulanan bir program varsa uygulanması ve program dahilinde müzik derslerinin zenginleştrilmesi; okul yönetimi- program yöneticisi- program uygulayıcı öğretmenlerin ve branş öğretmenlerinin hizmet içi eğitim programları ile güncellik kazanmaları, öğrencilerin durumunun hassasiyeti açısından veliler ile iş birliği içinde çalışılması önerilmektedir. 


\section{Kaynakça}

Akçamete, G. \& Avcıoğlu H. (2005). Sosyal becerileri değerlendirme ölçeğinin (7-12 yaş) geçerlik ve güvenirlik çalışması. Abant İzzet Baysal Üniversitesi Ĕ̆itim Fakültesi Dergisi, 5(2), 6177.

Akgünlü, S., Server, D., Düzgün, Z. \& Bükük, A. (2005). Karakter Gelişimi Ve Sosyal Beceri Eğitimi Ders Kitabı. KKTC Milli Eğitim ve Kültür Bakanlığı Yayınları.

Akkök, F. (1996). İlköğretimde Sosyal Becerilerin Gelişstirilmesi. Milli Eğitim Bakanlığı Talim ve Terbiye Kurulu Başkanlığı.

Altıntaş, E. \& Özdemir, A.S. (2012). The determination of the ideas of the teachers in Turkey about the Gifted Students. Procedia - Social and Behavioral Sciences (46), 2188 - 2192. https://doi.org/10.1016/j.sbspro.2012.05.452

Altun, F. \& Yazıc1, H. (2010). Learning styles of the gifted students in Turkey. Procedia Social and Behavioral Sciences 9, 198-202.

Atterbury, B. (1990). Mainstreaming exceptional learners in music. Englewood Cliffs,. Prentice-Hall, Inc.

Başer, F. (2004). Müziğin Okul Öncesi Dönemde Çocuk Gelişimine Katkısı. Sakarya Üniversitesi Eğitim Fakültesi Dergisi. Cilt 0, Sayı 8.

Best, J.W. \& Kahn, J.V. (2017). Eğitimde Araştırma Yöntemleri (Çev.Ed.Köksal, O.) 6.Bölüm: Deneysel ve Yarı Deneysel Araştırma. (Böl.Çev. Çepni, O. ve Kılınç. A.Ç.), s. 177-218. Eğitim Yayınevi.

Bilgiç, N. Taştan, A.,Kurukaya, G., Kaya, K., Avanoğlu, O. \& Topal, T. (2013). Özel Yetenekli Bireylerin Eğitimi Strateji ve Uygulama Klavuzu. Milli Eğitim Bakanlığı: http://orgm.meb.gov.tr/meb_iys_dosyalar/2013_11/25034903_zelyeteneklibireylerineitimis tratejiveuygulamaklavuzu.pdf

Büyüköztürk, Ş., Kılıç, E.Ç., Akgün, Ö.E., Karadenız, Ş. \& Demırel, F. (2009). Bilimsel Araştırma Yöntemleri (4.Bask1). Pegem.

Chandler, K. (2015). Recommendations for Practice:Designing Curriculum for Gifted Students. Turkish Journal of Giftedness and Education, 5(2), 157-166.

Clarke, S., Rowley, J.L. (2008). The Musical Education of Academically Gifted and Talented Students. Victorian Journal of Music Education,11(1), 31-37.

Clarke, S. (2006). The Musical Education of Academically Gifted and Talented Students: Teachers and Students Perspecties. A thesis submitted in partial fulfillment of the requirements for the degree of Bachelor of Music (Music Education) (Honours),Sydney Conservatorium of Music. Sydney, University of Sydney.

Clarke, S. (2006). The Musical Education Of Academically Gifted And Talented Students: Teachers' And Students'perspectives. A thesis submitted in partial fulfillment of the requirements for the degree of Bachelor of Music (Music Education) (Honours),Sydney Conservatorium of Music University of Sydney.

Çepni, S. (2005). Araştırma ve Proje Çalışmalarına Giriş. Erol Ofset.

Çetin, F., Bilbay, A.A. \& Kaymak, D.A. (2001). Çocuklarda Sosyal Beceriler. Epsilon.

Dağlığlu, E. (2010). Üstün Yetenekli Çocukların Eğitiminde Öğretmen Yeterlikleri Ve Özellikleri . Millî Eğitim Dergisi, MEB Yayınlarl, 186 (72-83). 
Ercan, Z. (2004 ). Üstün Yetenekli Öğrencilerin Eğitimi İçin Temel Prensipler ve Kullanılan Teknikler. 1. Türkiye Üstün Yetenekli Çocuklar Kongresi (s. 145- 159). Marmara Üniversitesi Atatürk Eğitim Fakültesi.

Erwin, P. (2000). Çocuklukta ve Ergenlikte Arkadaslık. O.Akınhay (Çev.). Alfa .

Goleman, D. (1998 ). Duygusal Zekâ. B. S. Yüksel (Çev.). Varlık.

Guenole, F.,Speranza, M.,Louis, J., Fourneret, P.,Revol,O. \& Baleyte, J.M. (2015). Wechsler profiles in referred children with intellectual giftedness: Associations with traitanxiety,emotional dysregulation, andheterogeneity of Piaget-like reasoning processes. European Journal of the Paediatric Neurology (19), 402-410.

Gülay, H. \& Akman, B. (2009). Okul Öncesi Dönemde Sosyal Beceriler. Pegem.

Güven, E. (2017). 12-14 Yaş Grubu Çocukların Müziğe İlişkin Tutumları İle Sosyal Beceri Düzeyleri Arasındaki İlişsinin İncelenmesi [Yayımlanmamış yüksek lisans tezi]. Başkent Üniversitesi Sosyal Bilimler Enstitüsü.

Heavner, T. (2005). The Applied Music Lesson: Teaching Gifted And Talented Students Utilising Principles Of Comprehensive Musicianship. International Education Journal, 6(2), 170174, ISSN 1443-1475

Hornby, A. (2000, (2000). ). Oxford Advanced Learnes's Dictionary of Current English (6.Baskl). $S$. Wehmeier (Ed.). Oxford University Press.

Ishak,N.M., Abidin, M.H.Z. \& Bakar, A.Y.A. (2014). Dimensions of social skills and their relationship with empathy among gifted and talented students in Malaysia. Procedia Social and Behavioral Sciences (116 ), 750 - 753.

Kara, N. (2020). Özel Yetenekli Öğrencilere Yönelik Kişiler Arası İletişim Becerilerini Destekleyici Program Modeli [Yayımlanmamış doktora tezi]. Sakarya Üniversitesi Sosyal Bilimler Enstitüsü.

Kelemen, G. (2010). A personalized model design for gifted children' education. Procedia Social and Behavioral Sciences (2), 3981-3987.

Keleş, A. (2020). Özel Yetenekli Davranış Problemlerinin ve Öğretmenlerin Bu Davranışlarla Baş Etme Yöntemlerinin Belirlenmesi [Yayımlanmamış yüksek lisans tezi]. Hacettepe Üniversitesi Eğitim Bilimleri Enstitüsü.

Ogelman, H.G., Seçer, Z., Alabay, E., Uçar, F. (2012). Okul Öncesi 5-6 Yaş GrubuÇocukların Bilişsel Gelişimleri İle Sosyal Becerileri Arasındaki İlişkinin İncelenmesi. Süleyman Demirel Üniversitesi Sosyal Bilimler Enstitüsü Dergisi, 1(15), 391-402.

Özmenteş, G. \& Bilen, S. (2005). Dalcroze Eurhythmıcs Öğretiminin Müziksel Beceriler, Müzik Dersine İlişkin Tutumlar ve Müzik Yeteneğine İlişkin Özgüven Üzerindeki Etkileri. İn̈nü Üniversitesi Ĕ̈itim Fakültesi Dergisi,6 (10), 87-102.

Root-Bernstein, R. (2015). Arts and crafts as adjuncts to STEM. Asia Pacific Education Review, DOI 10.1007/s12564-015-9362-0.

Sternberg, R. (2004). Definitions and Conceptions of Giftedness, ISBN: 1-4129-0427-7. Cowin Press.

U.S. Commissioner of Education. (1972). Education of the Gifted and Talented. U.S. Governtment Printing Office. 
Yıldırım, H. (2020). Özel Yetenekli Öğrencilerin Sosyal-Duygusal Beceri Algıları ile Akran İlişkileri Arasındaki İlişkinin İncelenmesi [Yayımlanmamış yüksek lisans tezi]. Hasan Kalyoncu Üniversitesi Sosyal Bilimler Enstitüsü.

Yüksel, G. (1997). Sosyal Beceri Eğitiminin Üniversite Öğrencilerinin Sosyal Beceri Düzeyine Etkisi. [Yayımlanmamış doktora tezi]. Gazi Üniversitesi Eğitim Bilimleri Enstitüsü.

Zeidner, M. \& Schleyer, E.J. (1999). Educational Setting and The Psyhosocial Adjustment of Gifted Studens. Studies in Educational Evaluation (25), 33-46.

\section{Beyan ve Açıklamalar (Disclosure Statements)}

1. Araştırmacıların katkı oranı beyanı / Contribution rate statement of researchers:

1. Yazar/First author $\% 50$,

2. Yazar/Second author $\% 50$.

2. Yazarlar tarafından herhangi bir çıkar çatışması beyan edilmemiştir (No potential conflict of interest was reported by the authors). 